\title{
Mimarlık Fakültesi Öğrencilerinin Gözünden Kent Merkezi Kullanımında Mesleki Algının ve Memnuniyetin Ölçülmesi
}

\section{Öğr. Gör. Dr. Hatice Gül Önder ${ }^{1 *}$}

Geliș tarihi: 22.08 .2019

Kabul tarihi: 17.09.2019

\section{Atıf bilgisi:}

IBAD Sosyal Bilimler Dergisi

Sayı: Özel Sayı $\quad$ Sayfa: 298-313

Yıl: 2019

This article was checked by Turnitin. Similarity Index 5\%.

1 Ankara Hacı Bayram Veli Üniversitesi, Türkiye, gul.onder@hbv.edu.tr.

ORCID ID 0000-0002-4794-6923

* Sorumlu yazar

\section{ÖZ}

İnsanlar, kişisel özellikleri, vizyonu ve bakış açısı dâhilinde bir kenti farklı şekilde algılamakta, mekânsal yer değişimine, gün içerisinde yaşanan olaylara, kişinin eğitim düzeyine hatta eğitim görülen alanın türüne bağlı olarak bu algı değiş̧kenlik göstermektedir. Öğrenciler, üniversite hayatına atıldıklarında bu farklılığı daha net kavrayabilmektedir. Yeni bir kent, yeni bir arkadaş ortamı ve yeni mesleki edinimler, öğrencilerin kentsel algısını ve kente aidiyet duygusunu yönlendirmektedir. Bu çalışmada, Gazi Üniversitesi Mimarlık Fakültesi'nde eğitim gören toplam 290 öğrencinin yüz yüze görüşme yöntemi ile uygulanan ankete katılımıyla, Ankara kent merkezi ve yakın çevresini kullanımlarına yönelik 9 soruluk anket formu öğrencilere yöneltilmiş ve kent merkezinin kullanımında mesleki algıdaki farklılıklar ve memnuniyet düzeyleri ölçülmüştür. Şehir ve Bölge Planlama bölümü öğrencileri kenti bir atölye ve çalışma alanı olarak görerek, kentin daha çok ișlevselliğini ön planda tutarken; Mimarlık bölümü öğrencileri kentin en önemli bileșenleri olan yapılara, yapılar ve çevre arasındaki ahenge odaklanmakta; Endüstri Ürünleri Tasarımı bölümü öğrencileri ise çoğunlukla kent merkezinin estetik ve görsel kaygılarla daha güzel tasarlanmış, eğlenceli ve sistematik bir mekân olması gerektiğini vurgulamışlardır. Böylece öğrencilerin, üniversite hayatı sürecince aldığı akademik eğitimin, kent merkezi algısı ve kent merkezinden beklentilerinde çeşitlilik yarattığı sonucuna ulaşılmıştır.

Anahtar Kelimeler: endüstri ürünleri tasarımı, kent merkezi, mesleki algı, mimarlık, şehir planlama 


\section{Measurement of Professional Perception and Satisfaction in the Use of the City Center by the Students of the Faculty of Architecture}

\section{Dr. Hatice Gül Önder ${ }^{1^{*}}$}

First received: 22.08 .2019

Accepted: 17.09.2019

\section{Citation:}

IBAD Journal of Social Sciences

Issue: Special Issue Pages: 298-313

Year: 2019

This article was checked by Turnitin. Similarity Index 5\%.

1 Ankara Hacı Bayram Veli Universitiy, Turkey, gul.onder@hbv.edu.tr,

ORCID ID 0000-0002-4794-6923

* Corresponding Author

\begin{abstract}
People perceive a city differently within their personal characteristics, vision and perspective, and this perception varies depending on the spatial displacement, the events experienced during the day, the level of education of the person, and even the type of field being educated. Students can comprehend this difference more clearly when they come up university life. A new city, a new friendship, environment and new professional acquisitions direct students' urban perception and sense of belonging to the city. In this study, a total of 290 students from Gazi University Faculty of Architecture participated in the questionnaire applied by face-to-face interview method. The questionnaire about the use of Ankara city center and its surroundings was directed to the students and the differences in professional perception and satisfaction levels were measured. While the students of the City and Regional Planning Department see the city as a workshop and working area, they prioritize the city's more functionality; Architecture students focus on the most important components of the city, the harmony between structures and the environment; The students of Industrial Design Department emphasized that the city center should be a better designed, fun and systematic place with aesthetic and visual concerns. Thus, it was concluded that the academic education received by students during university life created diversity in the perception of the city center and their expectations from the city center.
\end{abstract}

Keywords: Industrial Product Design, City Center, Professional Perception, Architecture, City Planning. 


\section{GİRIŞ}

Kentsel yapılı alanların gün geçtikçe artışı, kullanıcılarla kentin sosyal alanları arasındaki ilişkiyi ve mekân algısını büyük ölçüde etkilemektedir (Rahman, Shamsuddin ve Ghani, 2015, s.624). İnsanların çevre algısı çoğunlukla özneldir ve kişiden kişiye değişkenlik gösterir (Langemeyer, Baró, Roebeling ve Gómez-Baggethun, 2015). Kentlerin daha iyi algılanması için, yollar, sınırlar, işaretler, düğümler ve bölgelerden oluşan kentsel formun bütün unsurlarını birlikte bulundurması gerekir. Böylece kentli, her türlü algısal malzemeyi kentte daha kolay bulabilecektir. Algılanabilir bir çevre aynı zamanda esnek olmalıdır. Bir noktadan bir diğer noktaya ulaşmak için farklı güzergâhlar kullanılabilmeli, farklı bakış açılarıyla çevre gözlemlenebilmelidir. Bir çevre güçlü bir karakteristiğe sahipse daha kolay keşfedilecek ve daha cazip hale gelecektir (Lynch, 2010, s.122).

Bireylerin fiziksel ve kültürel özelliklerine bağlı olarak ortaya çıkan duygusal algıları, mekâna aidiyet hissiyle şekillenir (Bott, Cantrill ve Myers, 2005). Binalar, insan ölçeğinde, göz hizasında ve yürüme mesafesinde olduğu müddetçe daha iyi algılanmaktadır (Tibbalds, 2012, s.39). İnsan ölçeğinde tasarlanmış binalar, mekân, yürüme alanı ve iyi malzemeyle kaplanmış yüzeyler, yaya konforunun belirleyicisidir ve aynı zamanda mekânsal aidiyeti artırır (Kumar, 2010). Yürünebilirlik, makul bir süre zarfinda belirli bir çaba harcayarak insanların farklı destinasyonlar arasındaki hareketi ve bu destinasyonlar arasındaki ilişkiyle ilgilidir. Varış noktasına yakınlık, bağlantı ve erişilebilirlik, bir alanın yürünebilir olarak adlandırılmasında önemli unsurlardır (Southworth, 2005). Bağlantı ve erişilebilirlik, yaya konforunu belirleyici en önemli kriterlerdir (Lo, 2009; Vojnovic, 2006). Bağlantı, başlangıç-varış noktaları arasındaki kolaylığa bağlı olarak yürüyüş güzergâhı seçimini etkileyen ana faktördür (Kumar, 2010). Erişilebilirlik, yürünebilirlik açısından önemli bir faktördür ve eğer bir alan erişilebilir olarak adlandırıyorsa, her kesimden kullanıcı için eşit imkân ve firsat sunuyor demektir (Zakaria ve Ujang, 2015, s.644). Çevre ne kadar çok yürümeye ilişkin özellik içerirse, toplu taşımaya yönelik imkânlar gelişmişse ve bu da yürüme aktivitesini teşvik edici özellik sergiliyorsa, daha da yürünebilir olarak algilanmaktadır (Brown, Werner, Amburgey ve Szalay, 2007).

Kentsel yeşil alanlar, insan sağlığının ve yaşam kalitesinin geliştirilmesine önemli düzeyde katkı sağlar ve fiziki çevrenin insanlarca algılanmasında büyük ilgi uyandırır (Lee ve Maheswaran, 2011; Maas, Verheij, Gronewegen, Vries ve Spreeuwenberg, 2006). Buna karşın kamusal alandaki bakımsızlık ve düzensizlik, o alanın kullanıcılar tarafından görsel ve estetik olarak algılanmasında olumsuz etki oluşturur (Tibbalds, 2012, s.74). Birçok koşulda kentsel alanlardan ve çevreden memnuniyet, yapım ve üretim süreçlerinden olumsuz etkilenmektedir. Ulaşım çalışmaları, titreşim, gürültü ve kirletici etkiye neden olurken (D’Apuzzo, Esposito, Festa ve Nicolosi, 2014; Kubek, Wiecek ve Grzesica, 2014), inşaat faaliyetleri toz ve gürültüye neden olarak, kişilerin bu süreçlerden olumsuz etkilenmesine ve memnuniyetsizliğe neden olabilir (Brezar, 2014).

Bir mekânın karakteri; mekânın amacı, işlevi, fiziki formu ve görünüşü gibi farklı sosyo ekonomik özelliklerin yanı sıra, orada yaşayanların kültürel değerlerine göre de değişkenlik gösterebilir. Bu durum kullanıcıların algısını etkileyebileceği gibi, aynı zamanda yönlendirebilir de. İnsanların ve kentsel mekândaki faaliyetlerin varlığı, kentin yaşanabilirliğini etkin kılmaktadır (Appleyard, 1981; Ismail, 2017). Yaşanabilirlik, bir sokağın kullanımını etkileyerek fiziksel kalitenin yükselmesini sağlayan önemli bir unsurdur.

Kamusal alandaki açık hava etkinlikleri, dış mekânın kalitesinden ve sahip olduğu fonksiyonlardan etkilenebilir, mekânsal kalite geliştikçe, açık hava etkinliklerinin kalitesinde de artış gözlenecektir. Açık alan aktiviteleri üç kategoride değerlendirilebilir (Gehl, 2011; Gehl, 2010; Türel, Yiğit ve Altuğ, 2007);

- Günlük gereksinimler; okul, iş, alışveriş etkinliği, otobüs beklemek vb. ulaşım ihtiyaçlarının karşılanması

- İsteğe bağl1 gereksinimler; yürüyüş yapmak, oturmak, dinlenmek, gezi-eğlence amaçlı dolaşım

- Sosyal gereksinimler; çocukların oyun oynama etkinliği, arkadaş-tanıdık buluşması, açık alandaki konser vb. sanatsal etkinliklerdir.

Kamusal alan, kullanıcılarının gereksinimlerini karşıladığı müddetçe kaliteli olarak adlandırılabilir (Jacobs, 1996). Kamusal bir alan, güvenli (Whyte, 1980; Carmona, Heath, Oc ve Tiesdell, 2012), 
konforlu, elverişli (Jacobs, 1996; Lynch, 1981) ve erişilebilir (Whyte, 1980; Carr, Stephen, Francis, Rivlin ve Stone, 1992; Jacobs, 1996) olmalıdır. Kamusal alan, mekânın kimliği ve o mekânı kullanan kişiler arasındaki etkileşimli bir sürecin ürünü olarak anlam kazandığı müddetçe, her türden kullanıcı tarafindan konforlu ve pozitif anlam yüklü olarak algılanır (Carr ve diğerleri, 1992).

Kent mekânının, engelliler, yaşlılar, çocuklar ve kadınların gibi farklı kullanıcı grupları tarafından algılanması ve kentsel memnuniyetinin ölçülmesine yönelik birçok çalışma bulunmaktadır. $\mathrm{Bu}$ çalışmalarda komşuluk birimleri, kent merkezi, ulaşım ve çevresel unsurlar açısından algı ve memnuniyet düzeylerine yönelik yapılan çalışmalar bunlardan sadece birkaçıdır (Xue, Gou ve Lau, 2017; Munira ve San Santoso, 2017; Ismail, 2016; Hanák, Marović ve Aigel, 2015; Widyaevan, 2015; Zakaria ve Ujang, 2015; Rahman ve Shamsuddin, 2010; Tibbalds, 2012; Türkoğlu, 1997). Ancak sadece üniversite öğrencileri açısından kent merkezinin nasıl algılandığı ve kullanıcı memnuniyetinin ölçülmesine yönelik bir çalışma bulunmamaktadır. Bu çalışma kapsamında Gazi Üniversitesi Mimarlık Fakültesi öğrencilerinin, mesleki eğitimleri boyunca değişen düşünce yapıları ve görüşleri sorgulanarak, kent merkezine yönelik algıları ve memnuniyet düzeyleri ortaya koyulmaya çalışılmıştır. Bu bağlamda Ankara kent merkezinin gelişiminin incelenmesi önem arz etmektedir.

\section{Ankara Kent Merkezinin Tarihsel Gelişim Süreci}

Kentsel makroform, arazi kullanımı ve ulaşım imkânlarının gelişimi arasında sıkı bir ilişki bulunmaktadır. Kentlerin ilk kurulduğu noktadan itibaren arazi kullanımının ve ulaşım imkânlarının kente eklemlenerek genişlemesi, zamanla kentlerin yağ lekesi şeklinde çepere yayılmasına, kurulduğu alan gereği lineer genişlemesine ya da topografik eşiklerden, afetlerden ve doğal oluşumlardan dolay1 kademe kademe farklı bölgelere taşınmasına neden olmuştur. Kent yayılıp genişledikçe, kentin merkezi noktasında her türlü imkâna ulaşılabilecek, farklı ticaret ve iş faaliyetlerini bünyesinde barındıran bir alan yoğunlaşması yaşanır. $\mathrm{Bu}$ alan kent özeği, çekirdek, ya da merkezi iş alanı olarak adlandırılmaktadır.

3 Temmuz 2017 tarih ve 30113 sayılı Planlı Alanlar İmar Yönetmeliği'nin 4. Maddesi'nde Merkezi İş Alanı (MİA), İmar planlarında, yönetim, turizm, sosyal, kültürel ve ticari amaçlı yapılar ile sosyal altyapı alanları için ayrılmış bölge olarak tanımlanmıştır. Bu bölgede büro, iş hanı, gazino, lokanta, çarşı, çok katlı mağaza, banka, otel, sinema, tiyatro gibi sosyo-kültürel tesisler, yönetimle ilgili tesisler, özel eğitim ve özel sağlık tesisleri ve benzeri yapıların bulunduğu alanlar yer alır, denmektedir. Yönetmelikle detaylı şekilde tanımlanan MİA'ya Gökçe tarafında yapılan çalışma ile farklı bir tanımlama getirilmiş ve MİA'yı bir kentte ofis binaları ve mağazaların en yoğun olduğu yerdir. Sosyo-kültürel faaliyetlerin ve eğlence alanlarını da içeren bu alan genellikle toplumun her kesiminden bireyin bir araya geldiği, ulaşım ve erişim bağlantılarının en yoğun olduğu kent merkezi çekirdeğini kapsayan alan olarak tanımlamıştır (Gökçe, 2000). Günay ise daha çok sosyolojik bir bakış açısıyla (2013, s.128) kent merkezini, kentin kalbi hatta beyni olarak adlandırmış, bu bağlamda MİA'yı uzmanlaşmış kişilerin yer seçtiği birimlerden oluşan, kentin ekolojik merkezinde olduğu varsayılır, hem trafiğin hem de ulaşım odaklarının yer aldığı ama esasında karar vericilerin bulunduğu yer olarak adlandırmıştır.

Ankara, hem Türkiye'nin merkezinde, hem de merkezi konumunun bir gereği olarak başkentlik özelliğiyle, zamana tanıklık etmiş, tarihiyle, kültürüyle, stratejik özellikleriyle bir değerler bütününe sahip önemli kentlerden biridir. Ankara'da başkent olmadan önce Ankara Kalesi önünden Ulus'a kadar olan lineer bir kent merkezi bulunmaktadır. Bu alanın iki ucundan birinde geleneksel üretim ve ticaret işlevlerinin yer aldığı Bedesten, Kapalı Hanları çevreleyen yollar ve Samanpazarı gibi açık pazar yerleri bulunur. Diğer uçta ise Taşhan'ın bulunduğu yönetsel işlevlerin de yer aldığı görece yeni kent merkezi yer alır (Bakırer ve Madran, 1984, s.110). O dönemde ortada iki merkez yoktur ancak iki ucu farklı çizgisel formda bir kent merkezi vardır (Bademli, 1987).

1923 yılında Ankara'nın başkent oluşuyla, ticari, yönetsel, üretim ve hizmet işlevlerine dayalı yeni gelişmelerle Ulus ve yakın çevresi kent merkezi olmuştur (Bademli, 1985 s.212-213). 1924 yılında Lörcher, kenti güney yönüne geliştiren ve kentin bugünkü kalbini oluşturan Kızılay Merkezi ve çevresini biçimlendiren Yenişehir'e ilişkin değerlendirmelerde bulunmuştur. Atatürk'ün Cumhurbaşkanlığ Köşkü için Çankaya'yı seçmesiyle kent merkezi Ankara Kalesi-Çankaya hattında gelişmiş ve Ulus ön plana çıkmıştır (ABB 2023 NiP, 2006). Lörcher Planı, tren istasyonu çevresini merkez yapmayı, Ulus merkezini bu yeni yapıyla bütünleştirmeyi amaçlamıştır (Günay, 2006, s.67). 
Jansen Planı, Ankara'nın o dönemde çekirdek alanını belirler (Günay, 2006:70). Jansen Planı'nda merkez ayrıca değerlendirilmemiş ancak Ulus bölgesi kentin merkezi iş alanı, Kızılay ise semt merkezi olarak düşünülmüştür. 1950'lerde Ulus kent merkezinin çekirdeği yeni MİA olmuştur. Kızılay ise üst gelirlilere hitap eden ticaret ve hizmet işlevlerinin yer aldığı alt merkez olmuştur (Bademli, 1987). 1945'lerden sonra Ulus çevresinde yerleşen düşük gelirli gruplar buradaki merkezin havasını değiştirmeye başlamıştır. Üst gelir gruplarının konut alanları ve Ulus'ta yer alan bir takım işlevler Kızılay'a kaymaya başlamıştır. Böylece Ulus işlevsel olarak boşalmış, Kızılay ise MİA özelliği göstermeye başlamıştır (Bademli, 1987; Cengizkan, 2006, s.48).

1957 Yücel-Uybadin Planı ile Avrupa kentleri için tanımlanan çekirdek alanın Ankara'daki oluşumu biçimlendirilmiştir (Günay, 2006, s.80). Planda MİA olarak Ulus kabul edilmiştir (Kıral, 2013, s.13). Kızılay'ın bu süreçte sadece yoğunlaşacağı öngörülmüş, Ulus esas merkez olarak kalmaya devam etmiş, Kızılay'da mevcut ikametgâhların yerini büro ve ticarethanelere terk etmeye başlamış, ancak Ulus esas merkez olarak kalmaya devam etmiştir (Uybadin ve Yücel, 1957, s.7; Cengizkan, 2006, s.32). 1985 yılında idari ve ticari hizmetler Kızılay bölgesinde yer seçmiş, Ulus'ta ise düşük gelirli gruplar ve kırsal yapıya yönelik ticaret ve hizmetler ile toptan ticaret ve depolama alanları yer almıştır. Kızılay MİA faaliyetleri açısından Ulus'u geride bırakmıştır. (ABB 2023 NIP, 2006, s.66).

1986-1999 döneminde merkez işlevleri, Kavaklıdere, Gaziosmanpaşa, Turan Güneş ve Yıldız bölgesine sıçramıştır. 2000'den sonra ise Balgat, Öveçler, Mebusevleri, Bahçelievler bölgesine merkez işlevleri sıçrama yapmıştır. Söğütözü, Çukurambar, Balgat, Eskişehir yolunu ve Konya yolunu odak olarak kabul eden merkez işlevlerinin sıçradığı yeni alanlar ortaya çıkmıştır (Gökçe, 2013, s.34).

2023 Başkent Ankara Nazım İmar Planı, Ankara kent merkezi çekirdeği ve merkez yakın çevresi olarak iki kademeli merkez yapılanması belirlemiştir. Ankara için çekirdek bölge, Ulus ve Kızılay'a ek olarak Tunalı Hilmi, Kavaklıdere, Çankaya uzantısında merkezi işlevli, karma ticaret kullanımlarının yer aldığı bölgedir. Merkez yakın çevresi ise, MİA’yı çevreleyen konut alanlarının olduğu, ulaşım ilişkileri nedeniyle merkezle bütünleşen ve merkez uzantılarının, özellikle ofis kullanımlarının yer aldığı etkilenme-geçiş bölgesidir (ABB 2023 NIP, 2006, s.516).

Günümüzde Ankara'nın tarihi merkezi olarak adlandırılan Ulus ve modern kültürel merkez olarak adlandırılan (ABB 2023 NiP, 2006, s.528) Kızılay iki farklı alanmış gibi görülse dahi, ticari alanlar, ulaşım imkânları ve kent merkezine ait birçok fonksiyonla kent merkezi bir bütün olarak algılanmaktadır. Gazi Üniversitesi Mimarlık Fakültesi de, kuzeyde Ankara Yüksek Hızlı Tren Garı ve Gençlik Parkı, güneyde Kızılay Meydanının bir uzantısı olan Gazi Mustafa Kemal Bulvarı, doğusunda Adliye, Sıhhiye ve hastaneler bölgesi, batısında Anadolu (Tandoğan) Meydanı ile çevrelenmiştir. Çalışma alanı, 2023 Başkent Ankara Nazım İmar Planına göre Merkez Planlama Bölgesi içerisinde yer almaktadır (Bkz. Şekil 1).

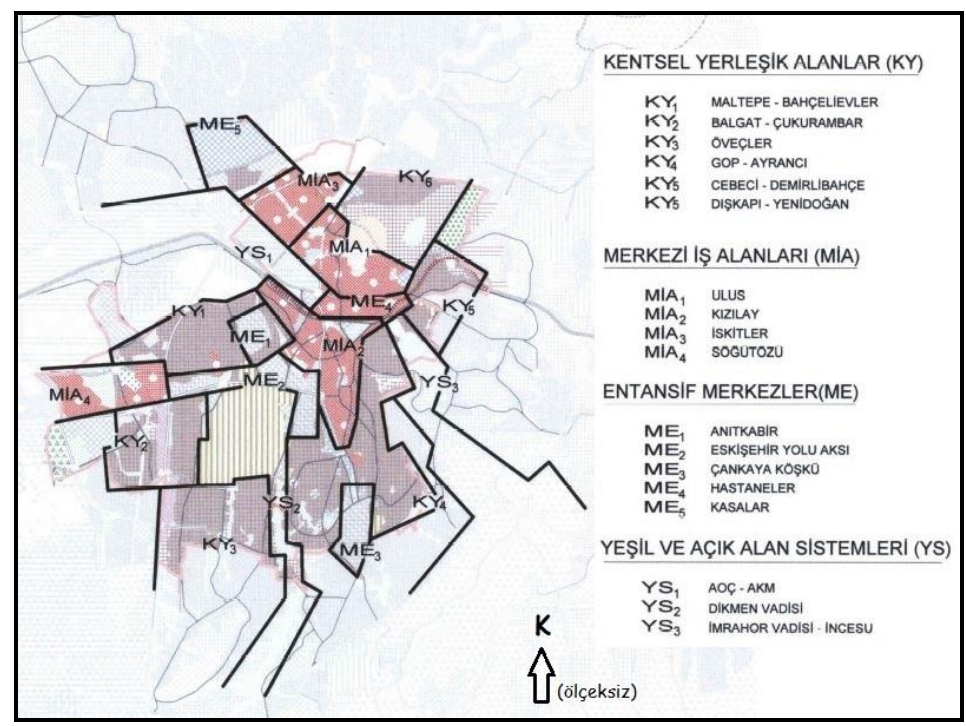

Şekil 1. 2023 Ankara Nazım İmar Planı Merkez Planlama Bölgesi (ABB 2023 NIP, 2006, s.535) 


\section{MATERYAL VE METOT}

Gazi Üniversitesi Mimarlık Fakültesi, Ankara'nın ticari kent merkezi olarak adlandırılan Kızılay ve tarihi kent merkezi olarak adlandırılan Ulus bölgesine yaklaşı $1,5 \mathrm{~km}$ mesafede yer almakta ve birçok kent merkezi fonksiyonuna farklı ulaşım türleriyle erişim mesafesinde bulunmaktadır. Çalışma kapsamında, anket örnekleminin belirlenmesi için ön değerlendirme yapılmıştır. Gazi Üniversitesi Mimarlık Fakültesi Öğrenci İşlerinden, Şehir ve Bölge Planlama, Endüstri Ürünleri Tasarımı ve Mimarlık Bölümlerinin, her dönem için aktif öğrenci sayısının toplamda yaklaşık 700 olduğu bilgisine ulaşılmıştır (2018), Bu bağlamda yüz yüze görüşme yöntemi vasıtasıyla toplam 290 öğrencinin ankete katılımının sağlanmasıyla, Ankara kent merkezi ve yakın çevresini kullanımlarına yönelik 9 soruluk anket formu öğrencilere yöneltilmiştir (Bkz. Ek-1).

Anket soruları, öğrencilerin cinsiyet, bölüm bilgisi, kent merkezi ve yakın çevresine erişimde kullanılan ulaşım türü, kullanım sıklı̆̆ ve kullanım süresi; bunun yanı sıra kent merkezi ve yakın çevresinin sosyalfiziksel-çevresel-mekânsal bağlamda algılanma düzeyi ile ilgili değerlendirmeleri içermektedir. Bunlara ek olarak, Gazi Üniversitesi Mimarlık Fakültesinin, Gazi Üniversitesi merkez kampüse taşınmas1 ihtimaline karşı, öğrencilerin kent merkezi ve yakın çevresini kullanım alışkanlığındaki olası değişimler, meslekleri açısından kent merkezinden beklentileri ve önerileri açık uçlu sorular yardımıyla elde edilmiştir.

\section{BULGULAR}

Ankara'daki üniversite öğrencilerinin tüm mahalleler bazında yaptıkları yolculuklar incelendiğinde, yaklaşık 610 mahalle içinde Kızılay bölgesi mahallelerinin (Korkut Reis, Kızılay, Sağlık, Cumhuriyet, Meşrutiyet Mahalleleri) \% 10'luk oranla en fazla yolculuk yapılan mahalleler olduğu belirlenmiştir (Bkz. Şekil 2).

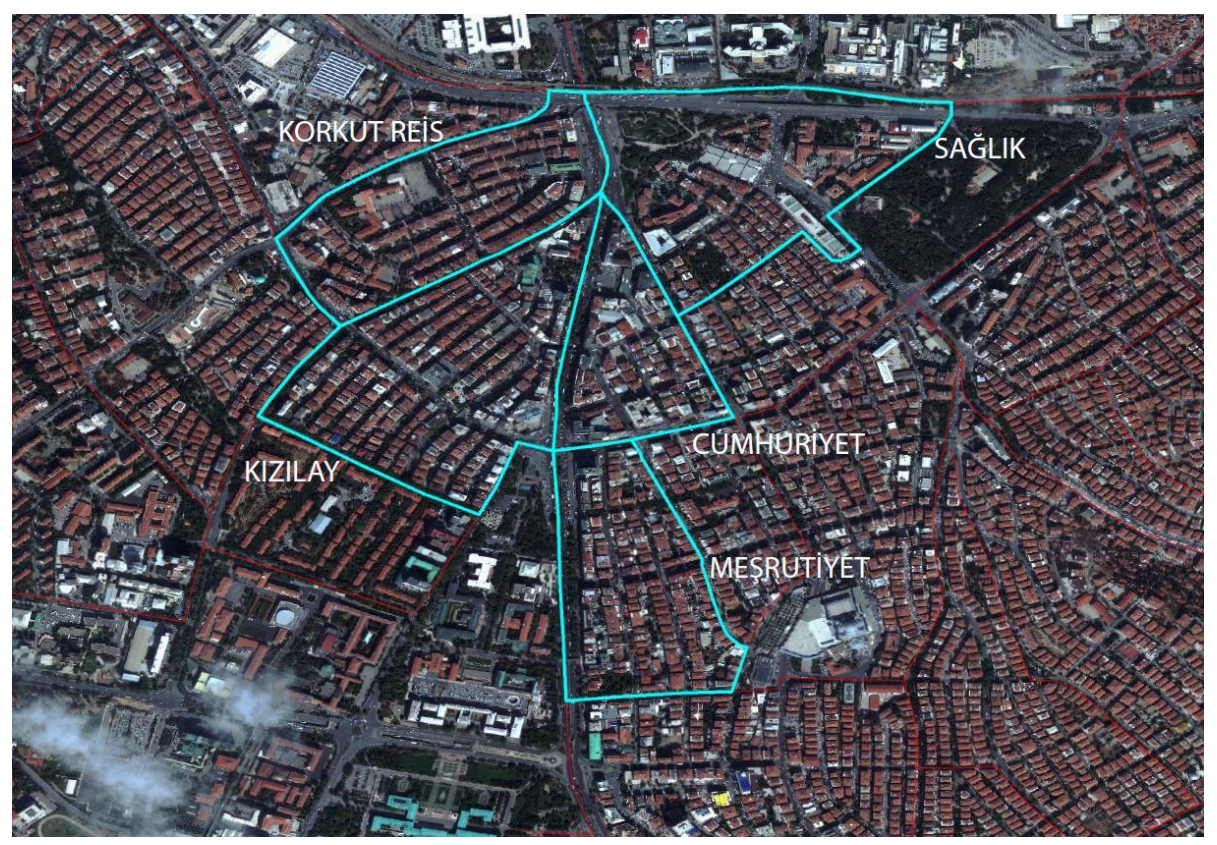

Şekil 2. Kızılay bölgesi mahalleleri

Kızılay bölgesinin kullanım amacına bakıldığında, Tablo 1'e göre, ilk sırayı \%34.76'lık oranla sosyalspor-eğlence amaçlı yolculuklar almakta, ikinci sırada \%23.17 ile okul amaçlı yolculuklar, üçüncü sırada ise \%14.84 ile alışveriş amaçlı yolculuklar yer almaktadır (AUAP, 2013). Bu oran aslında üniversite öğrencilerinin kent merkezini hangi amaçla kullandığına ve üniversite öğrencilerinin kent merkezini kullanım önceliklerine yönelik fikir vermektedir. 
Tablo 1. Tüm mahalleler bazında Kızılay bölgesi varışlı yolculuk amaçları* (AUAP, 2013)

\begin{tabular}{lrr} 
Kızılay bölgesi varışlı yolculuk amaçları & N & $\%$ \\
\hline Ev & 10 & $3.46 \%$ \\
İş & 54 & $5.69 \%$ \\
Okul & 160 & $23.17 \%$ \\
İş takibi & 10 & $1.02 \%$ \\
Alışveriş & 142 & $14.84 \%$ \\
Sosyal-spor-eğlence & 322 & $34.76 \%$ \\
Hastane sağlık merkezi & 2 & $0.20 \%$ \\
Şehir diş1 & 0 & $0.00 \%$ \\
Arkadaş ziyareti & 36 & $4.88 \%$ \\
Diğer & 100 & $11.99 \%$ \\
\hline *Tablodaki veriler, AUAP hanehalkı anketlerinden yeniden üretilmiştir.
\end{tabular}

Çalışma kapsamında, Gazi Üniversitesi Mimarlık Fakültesi öğrencileri ile yapılan anket sonuçları değerlendirildiğinde, katılımcıların \%73.10'unun kadın ve \%26.90'ının de erkek öğrencilerden oluştuğu; eğitim görülen bölümün açısından bakıldığında, katılımcıların \%43.45'inin Şehir ve Bölge Planlama bölümü, \%40.69'unun Endüstri Ürünleri Tasarımı bölümü, \%15.86'sının ise Mimarlık bölümü öğrencilerinden oluştuğu Şekil 2 ve Şekil 3'deki grafiklerde görülmektedir.

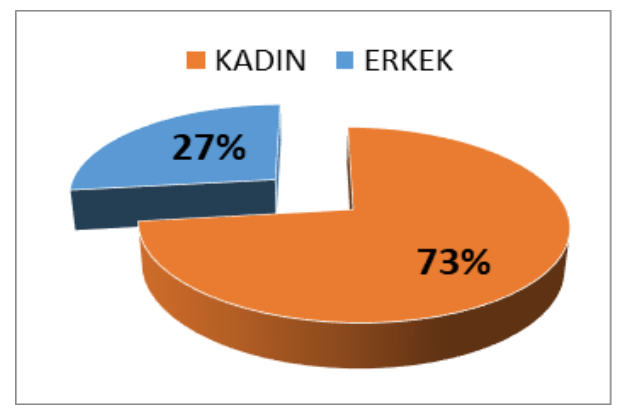

Şekil 2.Cinsiyet

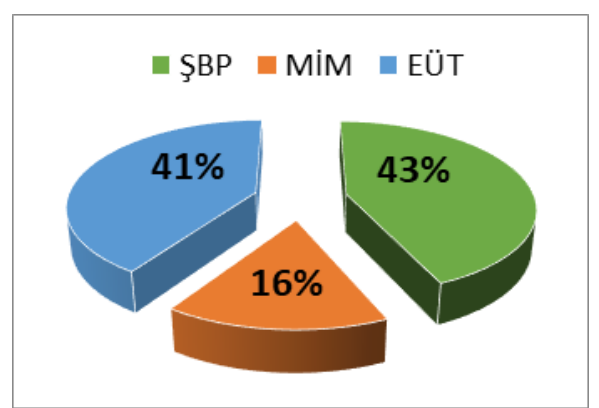

Şekil 3. Eğitim görülen bölüm

Öğrencilerin, kent merkezi ve yakın çevresine erişimde, yaya, bisiklet, özel otomobil, toplu taşıma ve servis gibi farklı ulaşım türlerini kullandıkları Tablo 2'de görülmektedir. Ulaşım türlerinde ilk üçte Ankaray ve Metro raylı sistemlerinin yanı sıra, yaya olarak erişim gerçekleştirildiği görülmektedir. Ulaşım türü kullanımında yüzdelik dağılımlara bakıldığında birinci sırada \% 70.34 'lık oranla Ankaray ile ulaşım yer alırken, \%69.31 ile Metro ikinci sırada, yaya ulaşım türü ise \%65.52 ile üçüncü sırada yer almaktadır. Diğer ulaşım türlerinde ikinci üçlüyü, lastik tekerli ulaşım türleri almaktadır. Bunlardan EGO belediye otobüsü $\% 58.97$, dolmuş $\% 54.11$ ve özel halk otobüsü de $\% 43.45$ 'lik bir paya sahiptir. Öğrenciler, kent merkezine ulaşımda çoğunlukla raylı sistemleri kullanmayı ya da yaya yürümeyi tercih ederken, lastik tekerli ulaşım türlerinin de yoğun olarak tercih edildiği belirlenmiştir. Yaya erişimin maliyetsiz olmasının yanı sıra; raylı sistemlerin aktarma imkânının bulunması nedeniyle bilet ücretinin lastik tekerli sistemlere kıyasla öğrenci bütçesine herhangi bir ek maliyet yüklememesi, daha çok tercih edilmesinde bir etken olarak ortaya koyulabilir.

Tablo 2. Öğrencilerin kent merkezi ve yakın çevresini kullanımda tercih edilen ulaşım türleri

\begin{tabular}{lrr} 
Ulaşım türü tercihleri & $\mathbf{N}$ & $\boldsymbol{\%}$ \\
\hline Ankaray & 204 & $70.34 \%$ \\
Metro & 201 & $69.31 \%$ \\
Yaya & 190 & $65.52 \%$ \\
EGO & 171 & $58.97 \%$ \\
Dolmuş & 157 & $54.11 \%$ \\
Halk Otobüsü & 126 & $43.45 \%$ \\
Özel araç & 72 & $24.83 \%$
\end{tabular}




\begin{tabular}{lrr} 
Taksi & 49 & $16.90 \%$ \\
Bisiklet & 4 & $1.38 \%$ \\
Servis & 4 & $1.38 \%$ \\
Banliyö & 4 & $1.38 \%$ \\
\hline
\end{tabular}

Ankaray'ın en fazla tercih edilme sebebi, Maltepe istasyonunun okula yaya yürüme mesafesinde yer almasıdır. Metro'nun okula en yakın olduğu noktalar Sihhiye ve Kızılay istasyonlarıdır. Öğrenciler çoğunlukla Metroyu kullandıkları zaman okula yaya olarak gelmeyi tercih etmiş ya da okul çıkışı Metroya yaya olarak ulaşımı tercih etme durumları söz konusudur. Bu durum kent merkezine yaya olarak ulaşımda dolaylı açıdan katkı sağlar. EGO ve Özel Halk otobüsü duraklarının Gazi Mustafa Kemal Bulvarı üzerinde yer alması nedeniyle öğrencilerin kent merkezine otobüsle ulaşımında kolaylık sağladığı ve tercih edilme oranının da yüksek olduğu görülmektedir. Aynı zamanda Sihhiye ve Anadolu Meydanı yönünden gelen ve Celal Bayar Bulvarından geçen birçok dolmuş hattının kentin Keçiören, Yenimahalle, Eryaman, Etimesgut, Çayyolu, Yaşamkent gibi yoğun yerleşim bölgelerine gidiyor olması, öğrencilerin kent merkezini kullanımda genellikle dolmuşu tercih etmelerini açıklamaktadır.

Öğrencilerin, Tablo 3'te yer alan kent merkezi ve yakın çevresine yaptıkları yolculuk amaçları incelendiğinde; yeme-içme ve arkadaş buluşması ilk sırada yer almakta, sonrasında okul ve alışveriş̧ amaçlı yolculuklar gelmektedir. Yeme-içme amaciyla yapılan kent merkezi yolculukları \%90.00, arkadaş buluşması yolculukları \%89.66' lık bir orana karşılık gelirken; okul amaçlı yolculuklar \%83.45, alışveriş amaçl1 yolculuklar \%78.97, gezinti-eğlence amaçlı yolculuklar \%66.21, ulaşım-aktarma amaçlı yolculuklar, \%64.14, sinema-tiyatro amaçlı yolculuklar ise \%56.21'lik bir orana sahiptir. Öğrencilerin kent merkezini yoğun olarak ticari imkânlardan faydalanma, eğitim, sosyalleşme ve kentin farkl1 noktalarına erişim amaçlı kullanması, kent merkezinin sahip olduğu fonksiyonlar göz önünde bulundurulduğunda, beklenen sonuçları vermektedir.

Tablo 3. Öğrencilerin kent merkezi ve yakın çevresini kullanım amaçları

\begin{tabular}{lrr} 
Yolculuk amacı & N & \% \\
\hline Yeme-içme & 261 & $90.00 \%$ \\
Arkadaş buluşması & 260 & $89.66 \%$ \\
Okul & 242 & $83.45 \%$ \\
Alışveriş & 229 & $78.97 \%$ \\
Gezinti-eğlence & 192 & $66.21 \%$ \\
Ulaşım-aktarma & 186 & $64.14 \%$ \\
Sinema-tiyatro & 163 & $56.21 \%$ \\
Kişisel-özel ihtiyaçlar & 120 & $41.38 \%$ \\
Hastane-sağlık merkezi & 74 & $25.52 \%$ \\
Kurs-dershane & 58 & $20.00 \%$ \\
PTT-Banka vb. ödeme & 58 & $20.00 \%$ \\
İş & 54 & $18.62 \%$ \\
Spor & 35 & $11.07 \%$ \\
Belediye vb. kamusal & 26 & $8.97 \%$ \\
\hline
\end{tabular}

Öğrencilerin kent merkezi ve yakın çevresini kullanım sıklığı Tablo 4’te yer almaktadır. Buna göre öğrenciler, Kızılay'1 \%57,9'luk bir oranla haftada birkaç gün kullandıklarını belirtmişlerdir. Bu durum, Kızılay'ın hem fakülteye yakın olması hem de öğrencilerin yolculuk amaçları tablosunda da yer aldığı gibi yeme-içme, arkadaş buluşması ve okul amaçlı birçok gereksinimin karşılanması açısından daha sık tercih edildiğini göstermektedir.

Öğrencilerin kent merkezi ve yakın çevresinde her gün ziyaret ettikleri alanlar incelendiğinde, Sihhiye \%20.7 ile ilk, YHT Garı \%18.6 ile ikinci, YHT Garı AVM kısmı\%16.6 ile üçüncü sırada yer almaktadır. $\mathrm{Bu}$ durum, öğrencilerin bu bölgeleri her gün ulaşım-aktarma amaçlı kullandıkları şeklinde açıklanabilirken; YHT Garı'nı kullananların aynı zamanda YHT Garı AVM kısmını da ziyaret ediyor olmaları, ulaşım amaçlı yolculukların yanı sıra, YHT Garındaki alışveriş-yeme-içme-arkadaşlarla boş zaman değerlendirme imkânlarını tercih ettiklerini göstermektedir. 
Bunlara ek olarak öğrenciler, Ulus Meydanı, Kocatepe Cami, Tunalı Hilmi Caddesini \%40-\%50 arasında değişen oranlarda; Ankara Kalesi, Hamamönü, Hastaneler Bölgesi, Gençlik Parkı, Kuğulu Park, gençlik Park1 ve Atatürk Orman Çiftliğini \%50-\%70 arasında değişen oranlarda, çoğunlukla hiç kullanmadıklarını belirtmişlerdir. Bu bölgelerin, Fakülteye uzak olmasının yanı sıra, öğrencilerin okul ve günlük hayatlarına ilişkin temel gereksinimlerine daha az hitap etmesi veya ilgili mekânların öğrenciler açısından cazibe oluşturmaması, tercih edilmemesinde bir neden olarak söylenebilir.

Tablo 4. Öğrencilerin kent merkezi ve yakın çevresini kullanım sıklığ

\begin{tabular}{|c|c|c|c|c|c|}
\hline Kullanım Sıklığı (\%) & Hiç & $\begin{array}{r}\text { Haftada } \\
\text { birkaç gün }\end{array}$ & Her gün & $\begin{array}{r}\text { Ayda } \\
\text { birkaç } \\
\text { gün }\end{array}$ & $\begin{array}{r}\text { Yılda birkaç } \\
\text { gün }\end{array}$ \\
\hline Kızılay Meydanı & $0.7 \%$ & $\mathbf{5 7 . 9 \%}$ & $15.2 \%$ & $21.4 \%$ & $4.8 \%$ \\
\hline Ulus Meydanı & $46.9 \%$ & $2.8 \%$ & $7.6 \%$ & $31.0 \%$ & $11.7 \%$ \\
\hline Sihhiye Meydanı & $22.8 \%$ & $17.9 \%$ & $20.7 \%$ & $35.2 \%$ & $3.4 \%$ \\
\hline Sakarya Caddesi & $24.8 \%$ & $26.2 \%$ & $0.0 \%$ & $40.7 \%$ & $8.3 \%$ \\
\hline Yüksel Caddesi & $24.1 \%$ & $33.8 \%$ & $2.1 \%$ & $31.0 \%$ & $9.0 \%$ \\
\hline Olgunlar Sokak & $25.5 \%$ & $23.4 \%$ & $0.0 \%$ & $40.0 \%$ & $11.0 \%$ \\
\hline Kocatepe Cami & $47.6 \%$ & $11.0 \%$ & $1.4 \%$ & $27.6 \%$ & $12.4 \%$ \\
\hline Tunalı Hilmi Caddesi & $44.1 \%$ & $14.5 \%$ & $2.1 \%$ & $24.1 \%$ & $15.2 \%$ \\
\hline Bahçelievler & $16.6 \%$ & $35.9 \%$ & $10.3 \%$ & $28.3 \%$ & $9.0 \%$ \\
\hline Beşevler & $16.6 \%$ & $35.2 \%$ & $13.1 \%$ & $30.3 \%$ & $4.8 \%$ \\
\hline Ankara Kalesi & $69.7 \%$ & $0.7 \%$ & $0.0 \%$ & $14.5 \%$ & $15.2 \%$ \\
\hline Hamamönü & $51.7 \%$ & $6.2 \%$ & $1.4 \%$ & $24.1 \%$ & $16.6 \%$ \\
\hline Hastaneler bölgesi & $\mathbf{5 7 . 9 \%}$ & $10.3 \%$ & $1.4 \%$ & $15.9 \%$ & $14.5 \%$ \\
\hline Anıtkabir & $24.8 \%$ & $13.1 \%$ & $5.5 \%$ & $32.4 \%$ & $24.1 \%$ \\
\hline YHT Garı & $29.0 \%$ & $33.1 \%$ & $18.6 \%$ & $12.4 \%$ & $6.9 \%$ \\
\hline YHT Garı AVM kısmı & $13.1 \%$ & $40.7 \%$ & $16.6 \%$ & $27.6 \%$ & $2.1 \%$ \\
\hline Gençlik Park1 & $\mathbf{5 7 . 9 \%}$ & $4.8 \%$ & $3.4 \%$ & $20.0 \%$ & $13.8 \%$ \\
\hline Kuğulu Park & $50.3 \%$ & $12.4 \%$ & $0.0 \%$ & $24.1 \%$ & $13.1 \%$ \\
\hline Kurtuluş Parkı & $63.4 \%$ & $6.9 \%$ & $2.1 \%$ & $21.4 \%$ & $6.2 \%$ \\
\hline Güvenpark & $31.7 \%$ & $25.5 \%$ & $2.1 \%$ & $34.5 \%$ & $6.2 \%$ \\
\hline Atatürk Orman Ciftliği & $69.7 \%$ & $1.4 \%$ & $0.7 \%$ & $15.2 \%$ & $13.1 \%$ \\
\hline
\end{tabular}

Kent merkezi ve yakın çevresinin kullanım süresine yönelik değerlendirmeler, Tablo 5'te verilmektedir. Buna göre öğrencilerin, Ulus ve yakın çevresinden çok, Kızılay ve yakın çevresinde daha çok zaman geçirdikleri belirlenmiştir. Anket sonuçlarına göre, Ulus, Ankara Kalesi, Hamamönü, Hastaneler bölgesinin, \%50-\%70 arasında değişen oranlarda çoğunlukla hiç kullanılmadığı görülmektedir. Sihhiye Meydanı, Sakarya Caddesi, Yüksel Caddesi, Olgunlar Sokak, Güvenpark gibi, öğrencilerin yoğun olarak gözlemlendiği bölgelerde, \%44-\%64 arasında değişen oranlarda, 1 saatten az zaman geçirdikleri görülmektedir. Öğrencilerin, kısa süreli ihtiyaçlarını karşılamak, ulaşım sistemlerine aktarma yapmak ve okudukları bölüm gereği ders malzemesi almak amacıyla bu bölgelerde daha kısa zaman geçirdikleri söylenebilir.

Tablo 5. Öğrencilerin kent merkezi ve yakın çevresini kullanım süresi

\begin{tabular}{lrrrrr} 
Kullanım Süresi (\%) & Hiç & 1 saatten az & $\mathbf{1 - 3}$ saat & 4-6 saat & $\begin{array}{r}\text { 7 saat ve } \\
\text { üzeri }\end{array}$ \\
\hline Kizılay Meydanı & & & & & $2.1 \%$ \\
Ulus Meydanı & $\mathbf{5 1 . 7 \%}$ & $31.7 \%$ & $\mathbf{4 6 . 2 \%}$ & $19.3 \%$ & $0.0 \%$ \\
Sihhiye Meydanı & $23.4 \%$ & $\mathbf{6 4 . 1 \%}$ & $9.0 \%$ & $1.4 \%$ & $2.1 \%$ \\
Sakarya Caddesi & $23.4 \%$ & $\mathbf{4 4 . 8 \%}$ & $25.5 \%$ & $4.8 \%$ & $1.4 \%$ \\
Yüksel Caddesi & $28.3 \%$ & $\mathbf{4 4 . 8 \%}$ & $22.8 \%$ & $4.1 \%$ & $0.0 \%$ \\
Olgunlar Sokak & $33.8 \%$ & $\mathbf{4 9 . 0 \%}$ & $12.4 \%$ & $4.1 \%$ & $0.7 \%$ \\
Kocatepe Cami & $49.0 \%$ & $35.9 \%$ & $12.4 \%$ & $0.7 \%$ & $2.1 \%$ \\
Tunalı Hilmi Caddesi & $45.5 \%$ & $14.5 \%$ & $21.4 \%$ & $14.5 \%$ & $4.1 \%$ \\
Bahçelievler & $16.6 \%$ & $4.1 \%$ & $\mathbf{3 9 . 3 \%}$ & $31.0 \%$ & $\mathbf{9 . 0 \%}$
\end{tabular}




\begin{tabular}{lrrrrr} 
Beşevler & $19.3 \%$ & $16.6 \%$ & $\mathbf{3 3 . 1 \%}$ & $22.1 \%$ & $\mathbf{9 . 0 \%}$ \\
Ankara Kalesi & $\mathbf{6 6 . 9 \%}$ & $9.7 \%$ & $21.4 \%$ & $2.1 \%$ & $0.0 \%$ \\
Hamamönü & $\mathbf{5 0 . 3 \%}$ & $13.1 \%$ & $24.8 \%$ & $11.0 \%$ & $0.7 \%$ \\
Hastaneler bölgesi & $\mathbf{7 0 . 3 \%}$ & $13.8 \%$ & $13.8 \%$ & $1.4 \%$ & $0.7 \%$ \\
Anıtkabir & $35.2 \%$ & $31.0 \%$ & $31.7 \%$ & $0.0 \%$ & $2.1 \%$ \\
YHT Garı & $33.8 \%$ & $37.9 \%$ & $26.2 \%$ & $1.4 \%$ & $0.7 \%$ \\
YHT Gar1 AVM kısmı & $12.4 \%$ & $25.5 \%$ & $\mathbf{4 9 . 7 \%}$ & $10.3 \%$ & $2.1 \%$ \\
Gençlik Park1 & $\mathbf{5 7 . 2 \%}$ & $24.8 \%$ & $15.2 \%$ & $2.1 \%$ & $0.7 \%$ \\
Kuğulu Park & $\mathbf{5 5 . 9 \%}$ & $20.7 \%$ & $20.0 \%$ & $3.4 \%$ & $0.0 \%$ \\
Kurtuluş Park1 & $\mathbf{6 7 . 6 \%}$ & $17.9 \%$ & $12.4 \%$ & $2.1 \%$ & $0.0 \%$ \\
Güvenpark & $40.7 \%$ & $\mathbf{4 9 . 0 \%}$ & $9.7 \%$ & $0.7 \%$ & $0.0 \%$ \\
Atatürk Orman Çiftliği & $\mathbf{7 1 . 0 \%}$ & $13.1 \%$ & $15.2 \%$ & $0.7 \%$ & $0.0 \%$ \\
\hline
\end{tabular}

Öğrencilerin kent merkezi ve yakın çevresini kullanırken, sosyal-fiziksel-çevresel-mekânsal algı düzeylerine yönelik değerlendirmelere, Tablo 6'da yer verilmektedir. Buna göre, kent merkezi ve yakın çevresine ilişkin 5.0 tam puan üzerinden yapılan puanlamaya göre;

- Kent merkezi ve yakın çevresinden istenilen her yere ulaşım imkânı, öğrenciler tarafından 5.0 puan ile en yüksek puanı almış ve kent merkezinin ulaşım açısından algılanma düzeyi çok iyi olarak değerlendirilmiştir.

- Kent merkezi ve yakın çevresinin erişilebilir olması, 4.6 ile ikinci en yüksek puanı almış ve öğrenciler tarafından algılanma düzeyi çok iyi olarak belirtilmiştir.

- Öğrenciler, gereksinim duydukları her şeyi kent merkezi ve yakın çevresinde bulabilme düzeylerini 3.8 puanla iyi olarak nitelemişlerdir.

- Öğrenciler yürünebilirlik açısından kent merkezi ve yakın çevresini 3.3 puanla iyi düzeyde yürünebilir olarak puanlamışlardır.

- Kent merkezi ve yakın çevresinde ışıklandırma imkânlarının yeterliliğini 2.8 puanla, güvenli olmasını ile sokak ve kaldırımların temiz olmasını 2.2 puanla ortalama düzeyde olarak belirtmişlerdir.

- Kent merkezi ve yakın çevresindeki kent mobilyalarının yeterliliğini 1.9 puanla ortalamaya yakın düzeyde ancak yetersiz olarak nitelemişlerdir.

- Öğrenciler, görsel açıdan kaliteli bir çevreye sahip olmasını 1.8 puanla, hava temizliği, yaşlı ve çocuk dostu olma durumunu 1.7 puanla, yeşil alan yeterliliğini 1.6 puanla, açık alan aktivitelerinin yeterliliğini ise ortalamaya yakın ancak kötü düzeyde puanlayarak, kent merkezi ve yakın çevresindeki yetersizliği belirtirken; otopark alanlarının yetersizliğini de yine 1.4 puanla kötü olarak nitelemişlerdir.

- Öğrenciler özellikle kent merkezi ve yakın çevresinin gürültülü bir alan olması hususunda hem fikir olarak 1.2 puanla, çok kötüye yakın düzeyde kötü olarak niteleyerek en düşük puanı bu seçeneğe vermişlerdir.

Tablo 6. Öğrencilerin kent merkezi ve yakın çevresini kullanıma yönelik puanlama

\begin{tabular}{lcccccr} 
Genel Değerlendirme (kişi) & $\begin{array}{c}\text { Çok } \\
\text { kötüi }\end{array}$ & Kötü & Ortalama & İyi & $\begin{array}{r}\text { Çok } \\
\text { iyi }\end{array}$ & $\begin{array}{r}\text { Puan } \\
\text { Değeri }\end{array}$ \\
\hline Sokak/kaldırımlar temiz & 35 & 208 & 379 & 88 & 10 & $\mathbf{2 . 2}$ \\
Havasi temiz & 66 & 236 & 307 & 7 & 10 & $\mathbf{1 . 7}$ \\
Erişilebilir & 11 & 32 & 213 & 609 & 193 & $\mathbf{4 . 6}$ \\
Yürünebilir & 18 & 87 & 432 & 280 & 71 & $\mathbf{3 . 3}$ \\
Engelli dostu & 95 & 277 & 132 & 48 & 0 & $\mathbf{1 . 4}$ \\
Yaşl1 dostu & 69 & 279 & 190 & 74 & 0 & $\mathbf{1 . 7}$ \\
Çocuk dostu & 70 & 255 & 234 & 41 & 20 & $\mathbf{1 . 7}$ \\
Güvenli & 46 & 230 & 265 & 152 & 11 & $\mathbf{2 . 2}$ \\
Gürültüsüz & 122 & 252 & 108 & 0 & 30 & $\mathbf{1 . 2}$ \\
Görsel açıdan kaliteli bir çevre & 80 & 233 & 203 & 87 & 21 & $\mathbf{1 . 8}$ \\
Işılandırma yeterli & 24 & 145 & 414 & 183 & 50 & $\mathbf{2 . 8}$ \\
Yeşil alanlar yeterli & 104 & 208 & 186 & 53 & 33 & $\mathbf{1 . 6}$
\end{tabular}




\begin{tabular}{lcccccc} 
Otopark alanları yeterli & 116 & 217 & 156 & 39 & 20 & $\mathbf{1 . 4}$ \\
Açı alan aktiviteleri yeterli & 99 & 221 & 215 & 9 & 30 & $\mathbf{1 . 5}$ \\
Kent mobilyaları yeterli (çöp kutusu, bank vb.) & 51 & 284 & 198 & 113 & 10 & $\mathbf{1 . 9}$ \\
Burada istediğim her şeyi buluyorum & 20 & 100 & 252 & 432 & 140 & $\mathbf{3 . 8}$ \\
İstediğim her yere buradan ulaşabiliyorum & 3 & 16 & 252 & 489 & 360 & $\mathbf{5 . 0}$ \\
\hline
\end{tabular}

Anket kapsamında öğrencilere yöneltilen iki açık uçlu sorudan ilki olan, "Fakültenizin Gazi Üniversitesi merkez kampüse taşınması durumu, kent merkezini kullanma alışkanlığınızı nasıl etkiler?” sorusuna verilen cevaplar incelendiğinde, bazı öğrenciler açısından mevcut durumlarında değişiklik yaşanmayacağı belirtilirken, bazılarının ise taşınma sürecinden farklı şekilde etkileneceği görülmüştür. Bu bağlamda öğrencilere göre fakültenin taşınması durumunda,

- Ulaşım daha da zorlaşacak, zaman kaybı yaşanacak,

- Okula ulaşırken yapılan mesafe ve yolda geçirilen süre artacak,

- Kent merkezi ve yakın çevresinin kullanım oranı azalacak,

- Kent merkezinin imkânlarından faydalanma düzeyi değişecek,

- Kent merkezi sadece ulaşım için aktarma amaçlı kullanılacak,

- Günlük aktivitelerde azalma yaşanacak,

- Alışveriş amaçlı yolculuk süresi uzayacak,

- Alternatif bir alışveriş alanı-ders malzemesi temin edilecek yere ihtiyaç duyulacak,

- İki ders arasındaki uzun süreleri değerlendirmek için farklı yer arayışına girilecek,

- Otobüs yerine metroyu kullanmak, manzarasız karanlık bir ortamda ulaşım yapmak zorunda birakacak,

- Okula yakın yeni bir ev-yurt binasına ihtiyaç duyulacaktır.

Mevcut durumda meydana gelecek bütün bu değişikliklerin aksine, Gazi Üniversitesi merkez kampüse taşınmanın, bazı öğrenciler açısından olumlu karşılanacağı algısı ortaya çıkmaktadır. Buna göre;

- Kent merkezinden uzaklaş1lsa dahi kampüste olmaya değecek,

- Kampüs ortamı, bir üniversitede okuyor olma algısını yükseltecek,

- Kampüsteki yeşil alanlar okul stresini atmaya firsat yaratacak,

- Kampüsün sosyo-kültürel imkânları bireysel gelişimi destekleyecek,

- Maltepe bölgesinden uzaklaşmak açısından olumlu olacak,

- Kızılay ve Ulus'tan ziyade Bahçelievler ve Beşevler gibi daha öğrenci dostu alanlar kullanılabilecek,

- Beşevler ve Bahçelievler yeme-içme, alışveriş ve sosyalleşme açısından daha çok kullanılır hale gelecektir.

Bir diğer açık uçlu soru kapsamında, öğrencilere yöneltilen "Mesleğiniz açısından baktı̆̆ınızda nasıl bir kent merkezi düşlersiniz?" sorusuna öğrencilerin, aldıkları akademik eğitimlerine göre farklı bakış açılarıyla cevap verdikleri gözlenmektedir. Buna göre;

Şehir ve Bölge Planlama bölümü öğrencileri, eğitim aldıkları bölüm gereği kentle ve özellikle kent merkezi ile ilgili konularda daha çok bilgiye sahiptir. Bu durum, mesleki eğitimleri vasıtasıyla, yaşadıkları kent mekânını iyi bir şekilde gözlemleyip algılamalarına fırsat sunmaktadır. Kentin ve kentsel unsurların her boyutunu farklı bakış açılarıyla değerlendirebilmektedir. Öğrencilerin, kent merkezinin sahip olması gereken özellikleri ve merkez fonksiyonundan beklentileri sıralanırsa, kent merkezinde;

- Taşıt ve otopark yoğunluğu azaltılmalı, insanlar için daha erişilebilir olmalı,

- Daha temiz ve güvenlik endişesi yaşamadan rahatça vakit geçirilmeli,

- Yaya sirkülasyonu artırılmalı, daha yürünebilir olmalı,

- Sürdürülebilir ve kolay erişilebilir olmalı,

- Toplu taşıma imkânları daha gelişmiş olmalı,

- Gençler için sosyal imkânlar artırılmalı,

- Toplumun farklı katmanlarından insanları birleştirmeli, 
- Dezavantajlı grupların daha güvenle kullanacağı bir merkez olmalı,

- Gürültü kirliliği olmamalı,

- Açık alan aktiviteleriyle desteklenerek cazibe merkezi haline getirilmeli,

- Kamusal alan ve yeşil alanlar artırılmalı, yeşil alanların sürekliliği sağlanmalı,

- Bisiklet güzergâhları ve parkları olmalı,

- Tarihi kent merkezinde yerel üreticileri destekleyici imkânlar sunulmalıdır.

Endüstri Ürünleri Tasarımı bölümü öğrencileri, meslekleri açısından kenti, tasarım unsurlarıyla zenginleştirilen, her kesimden insana hitap eden sistematik bir mekân olarak algılamaktadır. Öğrencilere göre kent merkezinde;

- Ulaşım imkânları gelişmiş ve kolay ulaşılabilir olmalı,

- İnsanları araç kullanmak yerine yaya yürümeye teşvik etmeli,

- Bisiklet yolları daha çok olmalı,

- Engellilerin kullanımına uygun tasarlanmış daha özgür alanlar olmalı,

- Daha yeşil ve güzel tasarlanmış olmalı,

- Geniş açık alanlar ve daha çok açık alan aktiviteleri olmalı,

- Ortak kullanım alanları insanlar açısından daha elverişli olmalı,

- Kent mobilyaları daha çok bulunmalı ve görsel açıdan kaliteli olmalı,

- Kalabalığın iyi yönlendirilebildiği alanlar olmalı,

- Üretim yöntemlerini tam anlamıyla öğrenebileceğim atölyeler olmalı,

- Proje materyallerimi kolay temin edebileceğim imkânlar olmalı,

- Daha düzenli ve sistematik bir alan olmalı,

- Gürültüsüz ve daha yaşanabilir olmalı,

- Sanat eserlerinin bulunduğu ve kültürel aktivitelerin yoğun olduğu yerler olmalı,

- Daha sosyal, eğlenceli ve pratik bir merkez olmalıdır.

Mimarlık bölümü öğrencileri, kent merkezini, yapıların oluşturduğu ya da yapılarla çevrelenen, işlevsel, modern, kaliteli ve iyi tasarlanmış bir mekân olarak algılamaktadır. Bu bağlamda kentsel fonksiyonlara, aldıkları mesleki eğitim açısından kent-bina ilişkisi ve tasarım ölçeğinde bakış açısı geliştirmektedirler. Öğrencilere göre kent merkezinde;

- Görsel açıdan daha iç açıcı olmalı,

- Daha iyi tasarlanmış, işlevsel bir mekân olmalı,

- Parklarda ve kaldırımlarda daha çok kent mobilyası bulunmalı,

- Ulaşılabilir ve kolay erişilebilir olmalı,

- Düzenli ve ferah olmali,

- Yeşil aks sürekliliği ile yaya yolları ayrıştırılmalı, geçişler güvenli olmalı,

- Meydanları ve ortak yaşam alanları çok olan, trafiğe kapalı alanlar olmalı,

- Modern sosyal donatılarla çevrelenmiş, sosyal yaşam alanları olmalı,

- Pek çok aktiviteye olanak veren daha estetik kaygılarla tasarlanmal1,

- Kent atölyelerinin bulunduğu mesleki yeterliliği artıracak alanlar olmalı,

- Daha samimi ve güven dolu alanlar olmalı,

- Engelli dostu bilinçli bir mimarisi olmalı,

- Doğayla uyumlu yapılarla çevrelenmeli,

- Açık ve yeşil alanlar daha çok bulunmalı,

- Kenti okuyan mimarlar tarafından tasarlanmış yapılar olmalı,

- Tek bir kesime hitap etmeyen, her kesimi kucaklayan kapsayıcı alanlar olmalıdır.

\section{SONUÇ VE ÖNERÍLER}

Üniversite hayatında edinilen bilgiler, kişinin iş hayatına atılırken karşılaşacağı zorlukları minimuma indirirken, aynı zamanda meslek alanı açısından pratik bilgilerin edinilmesiyle şekillenen bir temele sahiptir. Edinilen pratik bilgiler öğrencilerin hayatlarının bu dönüm noktasında farklı unsurları kıyaslayarak mesleki edinimleri ile birlikte gerçek hayata farklı bir bakış açısıyla yaklaşmalarına neden 
olmaktadır. Yapılan bu çalışma ile, öğrencilerin bazı durumlarda, kent merkezi ve yakın çevresindeki belirli bölgeleri daha sık ziyaret ettikleri ve bu bölgelerde daha uzun zaman harcadıkları görülürken; bazı bölgelerin neredeyse hiç ziyaret edilmediği, daha az sıklıkla ziyaret edilse dahi, daha kısa zaman geçirildiği gözlenmiştir. Bu durumun öğrencilerin ilgi ve merak düzeylerine göre değişmesinin yanı sıra, çalışma kapsamında farklı çıkarımlar yapılabileceği de açıktır. Çalışma sonuçlarına göre yapılan tespitler şöyledir;

- Şehir ve Bölge Planlama bölümünde verilen eğitim; öğrencilere kent planlama ve kentsel tasarım becerisi kazandırmayı amaçlarken, bu iki kavramı, teorik, çevresel, hukuksal ve teknik çerçeve ile destekleyen bir eğitim altyapısı sunmaktadır. Kent ve kentlinin yaşam kalitesini yükseltecek ilkeler ve önceliklerle mekansal analiz ve algılama sisteminin geliştirilmesi sağlanmaktadır. Böylece, Şehir ve Bölge Planlama bölümü öğrencileri kent merkezine yönelik algısında; insan odaklı ulaşımı, taşıt yoğunluğunun azaltılması, toplu taşımaya öncelik verilmesi, daha yüksek yaşam kalitesini, yeşil alanların ve çevresel kalitenin korunmasını, yürünebilir, kolay erişilebilir ve çevresel değerler açısından sürdürülebilirliği ön planda tutmaktadır.

- Endüstri Ürünleri Tasarımı bölümünde verilen eğitim; çizgisel bütünlük, süreklilik, ürün ve sarf malzeme temini, estetik-sanatsal kaygılar, hem ürünün kullanılabilirliği hem de ürün üretiminde teknik bakış açısını birleştirerek ve daha çok işlev-biçim kavramlarında bütünleşerek toplum, tüketici ve üreticiye yararlı olacak şekilde yaratıcı düşüncenin sunulmasını sağlayan bir çerçeveyi sunmaktadır. Dolayısıyla, Endüstri Ürünleri Tasarımı bölümü öğrencileri kent merkezine yönelik algısında; kolay ulaşılabilirliği, ortak kullanımda elverişliliği, sosyal, özgür ve engelli dostu mekânları, kent mobilyaları ve sanatsal unsurlarla bütünleşmiş daha güzel tasarlanmış, eğlenceli, estetik ve sistematik bir kent mekânını göz önünde bulundurmaktadır.

- Mimarlık bölümünde verilen eğitim ise; eğitim-öğretim alanında mesleki değişimlere ve gelişmelere uyum sağlayan, daha çok araştırma ağılıklı, yenilikçi ve yaratıcılığı ön plana çıararak, yapı ve çevresine yönelik mimari unsurları yorumlarken, estetik-işlevsellik-görsellik üzerine temellenen bir çerçeve sunmaktadır. Bu bağlamda Mimarlık bölümü öğrencileri, kent merkezine yönelik algısında; her kesimden insanı kapsayan, samimi ve güven dolu bilinçli bir mimariye sahip, ortak yaşam alanlarında modern sosyal donatıların yer aldığı, düzenli, ferah ve işlevsel açıdan iyi tasarlanmış kent mekânında, görsel ve estetik kaygıları temel almaktadır.

- Her üç ögrenci grubunun da proje-ders malzemesi gereksinimleri, onları her türden ihtiyaçlarını karşılayabilecekleri kent merkezine bağımlı kılmaktadır.

- Öğrenciler, YHT Garından çok YHT Garı AVM kısmında daha fazla zaman geçirmektedir.

- Öğrencilerin Bahçelievler ve Beşevler bölgesinde daha çok süre bulunmalarının temel nedeni yeme-içme, sosyalleşme ve alışveriş imkânlarının öğrenci yurtlarına yakın mesafede olmasıdır.

- Öğrencilerin, Kızılay ve Ulus bölgesinin kalabalığından uzaklaşmak için Bahçelievler ve Beşevler bölgesini tercih ettikleri, bunun yanı sıra bu bölgenin sosyal yapısının daha nitelikli olmasının, tercih edilmesinde önemli bir neden olduğu görülmektedir.

Öğrencilerin anketler vasıtasıyla ortaya çıkan görüşleri göz önünde bulundurulduğunda, kent merkezi ve yakın çevresine yönelik önerilerin geliştirilmesi önem arz etmektedir. Buna göre;

- Kent merkezinde aktarma noktaları birbirine daha yakın olmalı ve ulaşım türleri arasında entegrasyon sağlanmalıdır.

- Kent merkezine giriş yapacak özel otomobil trafiğini azaltmak için, kent merkezine giriş ücretlendirilmeli ve Park et-devam et sistemi, mevcut ulaşım sistemine entegre edilmelidir.

- Kent merkezinde hareketli trafiğin yanı sıra duran trafiğin (park etmiş araçların) de önlenmesi, merkezin yaya ve bisikletli gibi motorsuz ulaşım türlerine terk edilmesi gereklidir.

- İnsan-mekân-zaman üçgeninde, insanların kaliteli zaman geçireceği fonksiyon alanlarının kent merkezinde konumlandırılması gereklidir.

- Öğrencilere yönelik açık alan aktiviteleri yeşil alanlarla entegre bir şekilde planlanmalı, öğrencilerin sosyal açıdan gelişimini destekleyecek imkanlar artırılmalıdır.

- Daha iyi tasarlanmış ve görsel açıdan kaliteli olmalıdır.

- Kentin kimliğini yansıtacak şekilde tasarlanmış kent mobilyalarına ve kent merkezini canlandıracak sanat eserlerine yer verilmelidir. 
- 24 saat aktif yaşayan, dinamik bir kent merkezi yaratılmalıdır.

Böylece kent merkezi ve yakın çevresinin en önemli kullanıcıları olan genç ve dinamik nüfusa daha çok hizmet etmesi teşvik edilecek; her türden kullanıcının temel gereksinimlerini hızlı ve etkin şekilde karşılayacağı, görsel, estetik ve çevresel açıdan nitelikli bir kent mekanı oluşturulmasına katkı sağlanabilecektir.

\section{KAYNAKÇA}

ABB-Ankara Büyükşehir Belediyesi (2006). 2023 Başkent Ankara nazım imar planı açıklama raporu, Ankara: ABB Yayınları.

Appleyard, D. (1981). Livable streets. London: University of California Press.

AUAP-Ankara ulaşım ana planı hanehalkı anketleri (2013).

Bakırer, Ö., \& Madran, E. (2000). Ankara kent merkezinde özellikle hanlar ve bedestenin ortaya çıkış1 ve gelişimi. Tarih İçinde Ankara (Eylül 1981, Seminer Bildirileri), 107-130.

Bademli, R. (1985). 1920-1940 döneminde eski Ankara'nın yazgısını etkileyen tutumlar. Mimarlık Dergisi, 23, 212-213.

Bademli, R. (1987). Ankara merkezi iş alanının gelişimi. Ankara 1985'ten 2015'e, Ankara: Ankara Büyükşsehir Belediyesi EGO Yayını, 154-162.

Bott, S., Cantrill, J. G., \& Myers Jr, O. E. (2003). Place and the promise of conservation psychology. Human Ecology Review, 10(2), 100-112.

Brown, B. B., Werner, C. M., Amburgey, J. W., \& Szalay, C. (2007). Walkable route perceptions and physical features: Converging evidence for en route walking experiences. Environment and behavior, 39(1), 34-61.

Carmona, M., Heath, T., Oc, T., \& Tiesdell, S. (2012). Public places-Urban spaces. UK: Routledge.

Carr, S., Stephen, C., Francis, M., Rivlin, L. G., \& Stone, A. M. (1992). Public space. UK: Cambridge University Press.

Cengizkan, A. (2005). 1957 Yücel-Uybadin imar planı ve Ankara şehir mimarisi. (Tansı Şenyapıll, Der.). Cumhuriyet'in 'Ankara's içinde, Ankara: ODTÜ Yayıncıllk.

D’Apuzzo, M., Esposito, M., Festa, B., \& Nicolosi, V. (2014). Modelling vibrations induced by underground railways in urban areas. In Second International Conference on Traffic and Transport Engineering (ICTTE). Belgrade, November 27-28, 496-504.

Gehl, J. (2011). Life between buildings: Using public space. Washington: Island Press.

Gehl, J. (2010). Cities for people. Washington: Island Press.

Gazi Üniversitesi Mimarlık Fakültesi Öğrenci İşleri Birimi (2018). 2018-2019 y1lı Mimarlık Fakültesi Kayıtlı ve Aktif Öğrenci Veri Tabanı.

Gökçe, B. (2013). Ankara kent merkezi’nin erken cumhuriyet döneminden günümüze planlanmasi; uygulama ve sorunları. Ankara Kent Merkezinin Dönüşümü: Geçmiş-Bugün-Gelecek Paneli, Ankara: TMMOB ŞPO Yayını.

Gökçe, B. (2000). Ankara metropoliten alan büyükkent bütünü merkezler yapısı değerlendirmesi. Yayımlanmamış yüksek lisans tezi, Gazi Üniversitesi, Fen Bilimleri Enstitüsü, Ankara.

Günay, B. (2006). Ankara çekirdek alanın oluşumu ve 1990 nazım imar planı hakkında bir değerlendirme. (Tansı Şenyapıll, Der.), Cumhuriyet'in 'Ankara'sı içinde, Ankara: ODTÜ Yayıncilik. 
Günay, B. (2013). Analiz ve tasarımlarla yeniden kızılay; kızlay üzerine ütopyalar. Ankara Kent Merkezinin Dönüşümü, Ankara Kent Merkezinin Dönüşümü: Geçmiş-Bugün-Gelecek Paneli, Ankara: TMMOB ŞPO Yayını.

Hanák, T., Marović, I., \& Aigel, P. (2015). Perception of residential environment in cities: a comparative study. Procedia Engineering, 117, 495-501.

Lo, R. H. (2009). Walkability: what is it?. Journal of Urbanism, 2(2), 145-166.

Ismail, W. H. W. (2016). Young visitors in the city: Their perceptions of heritage buildings. ProcediaSocial and Behavioral Sciences, 234, 470-477.

Ismail, W. H. W. (2017). Users' perceptions of shopping activities in the historic city of Malacca. Asian Journal of Environment-Behaviour Studies, 2(3), 99-108.

Jacobs, A. B. (1996). Great streets. Cambridge, Massachusetts: The MIT Press.

Kıral, Ö. (2013). Ankara kent merkezi'nin erken cumhuriyet döneminden günümüze planlanması; uygulamaları ve sorunları. Ankara Kent Merkezinin Dönüşümü, Ankara Kent Merkezinin Dönüşümü: Geçmiş-Bugün-Gelecek Paneli, Ankara: TMMOB ŞPO Yayını.

Kubek, D., Wiecek, P., \& Grzesica, D. (2014). Speed limit evaluation based on pollutant estimation in urban highway: case study in Cracow. In Second International Conference on Traffic and Transport Engineering (ICTTE). Belgrade, November 27-28, 517-524.

Kumar, R. (2010). Walkability of neighborhoods: a critical analysis of the role played by zoning codes in creating a walkable environment. Germany: LAMBERT Academic Publishing.

Langemeyer, J., Baró, F., Roebeling, P., \& Gómez-Baggethun, E. (2015). Contrasting values of cultural ecosystem services in urban areas: The case of park Montjuïc in Barcelona. Ecosystem Services, 12, 178-186.

Lee, A. C. K. ve Maheswaran, R. (2011). The health benefits of urban green spaces: a review of the evidence. Journal of Public Health, 33(2), 212-222.

Lynch, K. (2010). Kent İmgesi. (çev. İrem Başaran). İstanbul: Türkiye İş Bankası Kültür Yayınları.

Maas, J., Verheij, R. A., Groenewegen, P. P., de Vries, S., \& Spreeuwenberg, P., (2006). Green space, urbanity, and health: how strong is the relation? Journal of Epidemiology Community Health, 60(7), 587-592.

Munira, S., \& San Santoso, D. (2017). Examining public perception over outcome indicators of sustainable urban transport in Dhaka city. Case studies on transport policy, 5(2), 169-178.

Rahman, N. A., Shamsuddin, S. \& Ghani, I. (2015). What makes people use the street? Towards a liveable urban environment in Kuala Lumpur city centre. Procedia - Social and Behavioral Sciences, 170, 624-632.

Rahman, N. A., \& Shamsuddin, S. (2010). User perceptions towards street characteristics and qualities that contribute to user friendly street. In Arte-polis, 3 International Conference: Creative Collaboration and the Making of Place, Learning from Shared Creative Experiences, Bandung, 22-24 July 2010: Proceedings, 1, 283.

Türel, H. S., Yiğit, E. M., \& Altuğ, İ. (2007). Evaluation of elderly people's requirements in public open spaces: a case study in Bornova district. Building and Environment, 42, 2035-2045.

Türkoğlu, H. D. (1997). Resident' satisfaction of housing environments: the case of Istanbul, Turkey, Landscape and Urban Planning, 39(1), 55-67.

Tibbalds, F. (2012). Making people-friendly towns: Improving the public environment in towns and cities. New York: Spon Press-Taylor \& Francis Group.

Uybadin, R. \& Yücel, N. (1957). Ankara imar planı izah notu. Rapor, Ankara. 
Vojnovic, I. (2006). Building communities to promote physical activity: a multi-scale geographical analysis. Geografiska Annaler: Series B, Human Geography, 88(1), 67-90.

Whyte, W. H., (1980). The social life of small urban spaces. Washington DC: The Conservation Foundation.

Widyaevan, D. A. (2015). The change of public perception towards alun-alun bandung as a city center. Procedia-Social and Behavioral Sciences, 184, 135-143.

Xue, F., Gou, Z., \& Lau, S. S. Y. (2017). Green open space in high-dense Asian cities: Site configurations, microclimates and users' perceptions. Sustainable cities and society, 34, 114-125.

Zakaria, J \& Ujang, N. (2015). Comfort of walking in the city center of Kuala Lumpur. Procedia - Social and Behavioral Sciences, 170, 642-652.

Planlı Alanlar İmar Yönetmeliği. (2017, 3 Temmuz) Resmi Gazete (Sayı: 30113). 16 Haziran 2019 tarihinde http://www.mevzuat.gov.tr/Metin.Aspx?MevzuatKod=7.5.23722\&MevzuatIliski=0\&sourceXml Search=Planl\%C4\%B1 adresinden erişildi. 